\title{
Characteristics of Secondary Caries Lesion around Composite Resin Restorations
}

\author{
Características da cárie secundária adjacente a restaurações de resina composta
}

Berenice Barbachan e Silva ${ }^{1}$, Débora Heller ${ }^{2}$, Marisa Maltz ${ }^{1}$

\section{Abstract}

Objective: The aim of this study was to analyze the features of secondary caries and their relationship with the presence of restorations marginal defects as gap, negative ledge (NL, lack of restorative material) and positive ledge (PL, overhang).

Materials and methods: Eighty proximal surfaces of Class II resin restorations were photographed and analyzed using a stereomicroscope (X40). It was recorded the presence of external secondary caries, gaps, NL, PL and after the restorations removal, the presence of internal lesion. All the exams were done in 10 welldefined points.

Results: The prevalence of secondary caries and gap were associated with gingival margin. The restorations marginal defects (NL and $\mathrm{PL}$ ) were not associated with any specific location (buccal, lingual or gingival). It was observed a relationship between these defects with secondary caries prevalence (gap: $p=0.004$; NL and PL: $p=0.017$ ). This association could be explained by the biofilm accumulation usually observed in the interface tooth surface/ restoration marginal defects. The presence of internal lesion was associated with external lesion. Although, in 141 points was observed internal lesion without the presence of external lesion. The majority of these lesions showed internal enamel involvement. Only $8 \%$ had demineralization restricted to dentine, which could suggest residual caries.

Conclusion: The results of this study showed that secondary caries lesion frequently began externally on the interface tooth/restoration, where diagnose, control and arrestment of the lesions is possible.

Keywords: secondary caries; diagnosis; stereomicroscopy

\section{Resumo}

Objetivo: O objetivo deste estudo foi analisar as características de cárie secundária e sua relação com a presença de restaurações com defeitos marginais como gap, degrau negativa (NL, a falta de material restaurador) e degrau positiva (PL, saliência).

Materiais e Métodos: Oitenta superfícies proximais de restaurações de resina classe II foram fotografados e analisados utilizando um microscópio estereoscópico (X40). Foi registrada a presença de cáries secundárias externas, gaps, NL, PL e após a remoção de restaurações, a presença de lesão interna. Todos os exames foram realizados em 10 pontos bem definidos.

Resultados: A prevalência de cárie secundária e gap foram associados com margem gengival. As restaurações com defeitos marginais (NL e PL) não foram associados a qualquer local específico (vestibular, lingual ou gengival). Observou-se uma relação entre esses defeitos com a prevalência de cárie secundária. A presença da lesão interna foi associada com lesão externa. Embora, em 141 pontos foi observada lesão interna, sem a presença de lesão externa. A maioria destas lesões mostraram envolvimento de esmalte interno. Apenas $8 \%$ tinham desmineralização restrito a dentina, que poderia sugerir cárie residuais.
${ }^{1}$ Professor of Department of Social and Preventive Dentistry, Faculty of Dentistry, Federal University of Rio Grande do Sul, Porto Alegre, Brazil

${ }^{2}$ Graduate student of Faculty of Dentistry, Federal University of Rio Grande do Sul, Porto Alegre, Brazil

Correspondência: Berenice Barbachan e Silva

Endereço: Faculty of Dentistry - UFRGS - Department of Social and Preventive Dentistry - Ramiro Barcelos, 2492 - CEP 90035-003, Porto Alegre - RS, Brazil Fone: (51) 3316-5193

E-mail: tchus@portoweb.com.br

Data de Submissão: 11/07/2011

Data de Aceite: 08/05/2012

Conclusão: Os resultados deste estudo mostraram que a lesão de cárie secundária frequentemente começa externamente na interface dente/restauração, onde diagnóstico e controle das lesões é possível. Palavras-chave: cárie secundária, diagnóstico, estereomicroscopia

\section{Introduction}

The diagnosis of secondary caries is a subjective topic, which can lead to an inappropriate indication of restorative treatment. This diagnosis is based on external indicators such as restoration defects, discoloration at the margins of the restorative material, microbial accumulation, and tooth-restoration gaps (KIDD; JOYSTONBECHAL; BEIGHTON, 1995; KIDD; BEIGHTON, 1996; FONTANA; GONZÁLES-CABEZAS, 2000; MAGALHÃES et al., 2009; LAl; LI, 2012). However, a number of studies have shown that external clinical indication is not efficacious in the diagnosis of secondary caries (GOLDBERG et al., 1981; KIDD; O'HARA, 1990; KIDD; JOYSTONBECHAL; BEIGHTON, 1994; KIDD; JOYSTON-BECHAL; BEIGHTON, 1995; RUDOLPHY; VAN AMERONGEN; PENNING, 1995; PIMENTA; NAVARRO; CONSOLARO, 1995; KIDD; BEIGHTON, 1996; RUDOLPHY; VAN LOVEREN; VAN AMERONGEN, 1996). Marginal defects prompt greater microbial accumulation, but this does not in and of itself cause secondary caries (ÖZER, 1997). The gap is associated with secondary caries and is responsible for an excessive number of restoration replacements (BEZNOS, 2001; HANNIG et al., 2009; HILTON, 2002a; MO et al., 2010). There has been much research about how to control or minimize gaps based on the belief that there must be an ideal seal between tooth and restoration in order to prevent secondary caries (NEME; EVANS; MAXSON, 2000; BEZNOS, 2001; DEMARCO et al., 2001; HILTON, 2002a; HILTON, 2002b; OKUDA et al., 2001; ITOTA et al., 2001; MANHART et al., 2001).

Nowadays, direct composite resin restorations are the most common choice in general practice (ANDERSON, 2001). This material has undergone improvements and is now even being used on posterior teeth with Class II cavities. Some authors report that this type of restoration is subject to microleakage and consequent secondary caries lesions of the cervical margins of the proximal boxes (KIDD; TOFFENETTI; MJÖR, 1992; MANHART et al., 2001; 
BEZNOS, 2001; DEMARCO et al., 2001). However, there is no scientific evidence regarding the relation between the presence of secondary caries and such gaps (ÖZER, 1997). The dental profession has focused great effort on the issue of restoration replacement, a procedure largely motivated by the need to control secondary caries. Understanding the characteristics of this lesion and its relation with the state of the adjacent restoration is vital. The aim of this study was to analyze the features of secondary caries and their relationship with the presence of restorations marginal defects as gap, negative ledge (NL, lack of restorative material) and positive ledge (PL, overhang).

\section{Materials and Methods}

Sixty extracted teeth (human premolars and molars) with Class II composite resin restorations (80 proximal boxes) comprises de sample from oral health services in Porto Alegre city, and from School of Dentistry's Human Teeth Banks at the University of São Paulo (São Paulo state), and at the Federal University of Pelotas (Rio Grande do Sul state) comprised the sample. In order to sterilize the teeth, they were stored in a $2 \%$ formol solution at $\mathrm{pH} 7$ for thirty days (White, 1987). No teeth displaying fractures or large cavitations $(<1254 \mu \mathrm{m})$ adjacent to the restoration were included. Proximal boxes that extended into buccal or lingual surfaces were also excluded.

Proximal boxes were photographed using a digital camera (Nikon D100, Nikon, Japan), coupled to a stereomicroscope at a magnification of 40X (Zeiss, SV 8, Germany). To establish standardized points of measurements for the recording of the variables at principal sites (Fig. 1), 10 points of analysis were defined on the proximal boxes and marked on the photographs (ÖZER, 1997) with the aid of image-processing software (Adobe Photoshop 6.0). Two occlusal points $\mathrm{A}$ and $\mathrm{J}$ were placed $500 \mu \mathrm{m}$ from the buccoocclusal and linguo-occlusal restoration corners. Points $D$ and $G$ were located at the bucco-gingival and linguo-gingival cavity margin corners. The distance between occlusal and cervical corner points was divided into thirds in order to define the location of intermediary buccal ( $B$ and $C$ ) and lingual $(\mathrm{H}$ and $\mathrm{I})$ points of measurements. The length of the cervical margin was also divided into thirds for definition of the other cervical points $(E$ and $F)$. The location of each of the 10 points of measurement was defined on each specimen separately (Fig. 1). A total of 798 sites were analyzed (2 sites were lost owing to contact with another restoration).

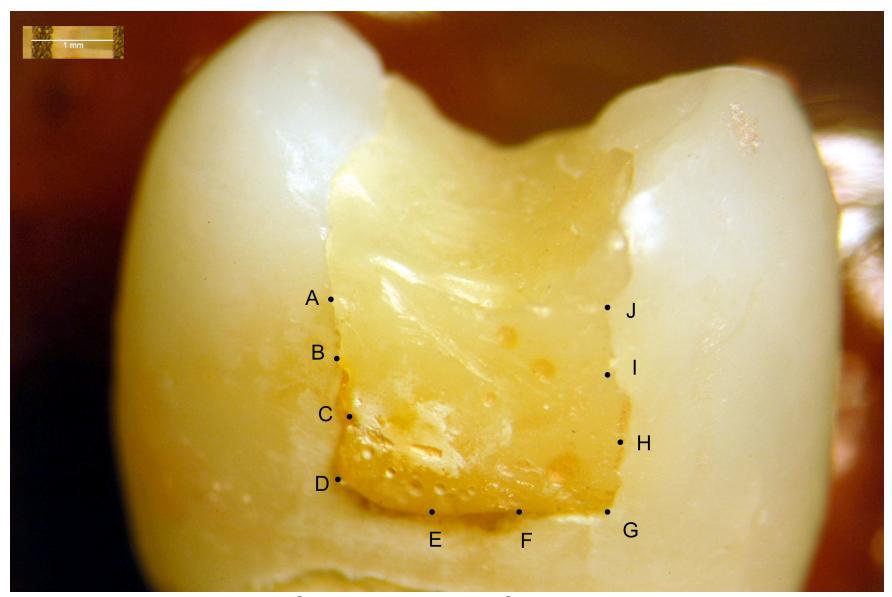

Figure 1: Example of the location of the 10 analyzed points at the proximal boxes of the restorations.
The analyses of caries lesions and the classification of restorations and gaps were conducted at different moments and were blind in relation to the exams. After drying surfaces for five seconds, the specimens were placed under a stereomicroscope at a magnification of $40 x$, at maximum light intensity (Zeiss, SV 8 , Germany).

The restorations were classified into: plane (on the same plane as the dental surface), with a negative ledge (restoration lower than the tooth, with an absence of restorative material), and those with a positive ledge (restoration higher than the tooth, with an excess of restorative material). The presence and size of the gaps were then ascertained at each of the points of analysis. Measurements were made using Adobe Photoshop 6.0. These procedures were not carried out on cavitated lesions ( 65 sites).

Caries lesions were classified as external lesions adjacent to a restoration and internal lesions in the cavity wall. External caries lesions were examined first (Table 1) and classified as active or inactive, with or without cavity. Active lesions without any cavity were those with whitish spots on opaque enamel, while inactive lesions were those with whitish or pigmented spots or pigmented with shiny enamel. When the cavitated lesions involved only the enamel, they displayed the same characteristics as non-caries lesions but with a loss of substance. The enamel parts of cavitated active lesions involving the dentine displayed the same characteristics as active lesions of the enamel, with the dentine softened and light yellow in color. In the case of cavitated inactive lesions involving the dentine, the enamel portion displayed the characteristics of inactive enamel lesions, with the dentine darkened, pigmented, and hardened.

Table 1. Criteria used for the stereomicroscopic classification of observed external caries

0 - Sound surface

1- Active lesion without cavity

2- Active cavity lesion

3- Inactive lesion without cavity

4- Inactive cavity lesion

Subsequently, the restorations were carefully removed so that the internal lesions could be examined. In order to weaken the restoration and facilitate its removal, avoiding any damage to the cavity wall, small channels were drilled on the surface with a round diamond burr 1012 (KG Sorensen, Brazil) on high rotation, beginning in the mesio-distal direction and possibly continuing in the occlusal or buccal/lingual direction. The restoration was then carefully removed with the aid of hand tools. The condition of the enamel-dentine cavity wall was also examined (Table 2). The characteristics of lesion activity were classified in the same way as in the examination of external caries. 
Table 2. Criteria used for the stereomicroscopic classification of observed internal caries

0- Cavity wall (CW) appears normal and hard without signs of staining and demineralization

1- The CW is like (0) but has indications of staining or remnants of restorative material

2- Enamel of the $\mathrm{CW}$ is with active lesion, but the enamel-dentine junction (EDJ) and the dentine is like (0) and (1)

3- Enamel of the $\mathrm{CW}$ is with inactive lesion, but the enamel-dentine junction (EDJ) and the dentine is like (0) and (1)

4- Enamel of the $\mathrm{CW}$ is normal, but the enamel-dentine junction (EDJ) and the dentine are with active lesion

5- Enamel of the CW is normal, but the enamel-dentine junction (EDJ) and the dentine are with inactive lesion

6- Enamel of the CW is with active lesion and the enamel-dentine junction (EDJ) and the dentine are also with active lesion

7- Enamel of the CW is is with inactive lesion and the enameldentine junction (EDJ) and the dentine are also with inactive lesion

Examinations of external and internal caries were performed by one examiner (BBS), while the examinations for presence, gap measurement, and restoration classification were performed by another examiner (DH). The reproducibility of examinations of external caries, restoration classification, presence of gap, and internal caries were measured using an unweighted Kappa coefficient, admitting a minimum value of 0.8 (FLEISS, 1981). The time between an exam and another was one week. This reproducibility was assessed at the start and following verification of $50 \%$ of the sample. The first and second examinations showed Kappa indexes for examinations of external caries, internal caries, gap presence, and restoration classification of, respectively: 0.88 and $0.94 ; 0.82$ and $0.94 ; 0.80$ and $0.87 ; 0.83$ and 0.90 . There was a week interval between the two exams. The gaps were measured three times with a one-hour interval over three days. Differences greater than $25 \mu \mathrm{m}$ were not allowed between measurements. The largest measurement was used in these analyses.

The software used for statistical treatment was SPSS (Statistical Package for Social Science) for Windows, version 8.0. Each site of a proximal box was deemed an analytical unit. In order to draw a relation between the presence or absence of a lesion, gap, and ledges and the location in the proximal box, a chi-squared test was performed, along with an analysis of adjusted residues. A nonparametric Kruskal-Wallis test was used to ascertain the difference in gap size at the points of analysis. The chi-squared test was conducted to test the relation between the presence of a lesion and gap and the presence of a lesion and ledges. A non-parametric Mann-Whitney test was performed to verify the relation between gap size and the presence of a lesion. The chi-squared test was conducted to test the relation between the presence of an external lesion and internal lesion. In order to associate this same relation to the presence of gap, an analysis of adjusted residues was also performed. The odds ratio for the variable outcome of the internal lesion was to test the relation to other variables in the study.

\section{Results}

In $54 \%$ of the cases, the external caries lesions presented without any cavity, while $60 \%$ were inactive. Of those lesions presenting a cavity, $52 \%$ were inactive. We observed a tendency for an association between: (a) the dental surface adjacent to the buccal/lingual sides of the proximal box and soundness and (b) the cervical margin and caries lesions $(p<0.05)$ (Fig. 2). Almost all sites with lesions presented ledges (88\%), while there was a gap in $39 \%$ of these cases. At the margins of the restoration, where the adjacent surface was sound, gaps were observed in $23 \%$ and the prevalence of ledges was $79 \%$.

The absence of gap was associated with the buccal/lingual location of the proximal box while its presence was associated with the cervical margin $(p<0.001)$ (Fig. 3). When analysis was conducted by site, the presence of gap was locally associated with cervical sites $G, E$, and $F$, and its absence was associated with occlusal sites $A$ and $J$ and buccal site $B(p<0.05)$.

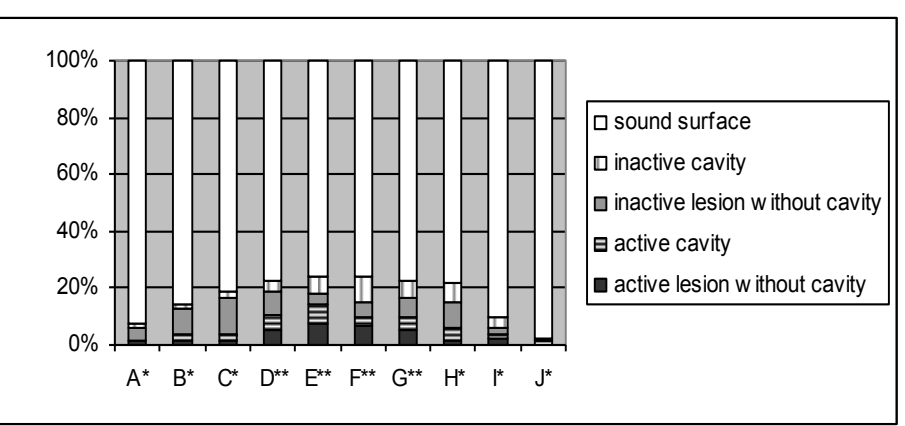

Figure 2: External caries examination in relation to the activity and progression at each analyzed point.

(Chi-squared test with analysis of adjusted residues, $p<0.05$ )

( ${ }^{*}$ sound surface tendency, ${ }^{* *}$ lesion tendency)

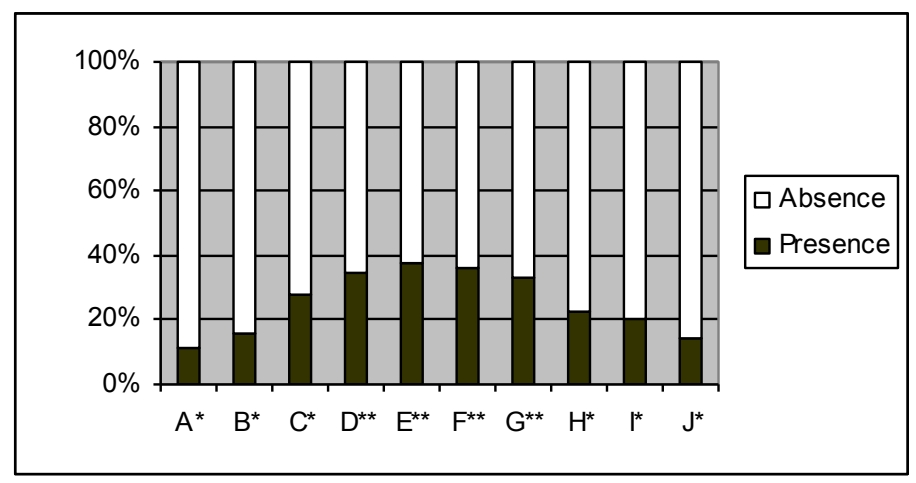

Figure 3. Presence of gap at each analyzed point.

(Chi-squared test with analysis of adjusted residues, $p<0.01$ )

( gap absence tendency, ${ }^{* *}$ gap presence tendency)

There was no statistical difference in measurements of gap size between sites $(p=0.169)$ (Table 3$)$.

It was observed that the absence of an external lesion was locally associated with the absence of gap, and the occurrence of a lesion, with this presence $(p=0.004)$. There was not also observed an association between gap size and presence of external lesion ( $p=$ 0.765) (Tables 4 and 5). 
Table 3. The median, distribution, and interquartil interval of gap size $(\mu \mathrm{m})$ at the points that presented a gap.

\begin{tabular}{|c|c|c|c|c|c|}
\hline $\begin{array}{l}\text { Relation to } \\
\text { the } \\
\text { surfaces }\end{array}$ & Points & $\begin{array}{c}\text { Points } \\
\text { with gap }\end{array}$ & Median & Distribution & $\begin{array}{c}\text { Interquartil } \\
\text { interval } \\
25 \%-75 \% \\
\end{array}$ \\
\hline \multirow[t]{2}{*}{ Occlusal } & $A$ & 9 & & $57.5-629,9$ & \\
\hline & $\mathrm{J}$ & 11 & 128.7 & 49.3-205.4 & $65.7-180.8$ \\
\hline \multirow[t]{2}{*}{ Lingual } & $\mathrm{H}$ & 21 & 156.1 & $49.3-356.0$ & $93.1-232.8$ \\
\hline & I & 12 & 147.9 & 49.3-446.4 & 97.9-197.9 \\
\hline \multirow[t]{2}{*}{ Buccal } & B & 15 & 126.00 & $32.9-298.5$ & 60.3-164.3 \\
\hline & C & 16 & 134.2 & $\begin{array}{c}38.3- \\
1196.8 \\
\end{array}$ & 65.7-213.6 \\
\hline \multirow[t]{4}{*}{ Cervical } & D & 23 & 136.9 & $\begin{array}{c}35.6- \\
2273.0\end{array}$ & $68.5-238.3$ \\
\hline & $E$ & 23 & 172.5 & 2177.2 & 347.8 \\
\hline & $F$ & 26 & 184.9 & $\begin{array}{c}49.3- \\
2084.1\end{array}$ & $\begin{array}{l}128.0- \\
299.2\end{array}$ \\
\hline & G & 24 & 175.3 & 2062.2 & 295.8 \\
\hline Total & & 180 & & & \\
\hline
\end{tabular}

Table 4. Relation between external lesion and gap at each analyzed point.

\begin{tabular}{|c|c|c|c|c|c|c|}
\hline \multirow{3}{*}{$\begin{array}{l}\text { External } \\
\text { lesion }\end{array}$} & \multicolumn{4}{|c|}{ Gap } & & \\
\hline & \multicolumn{2}{|c|}{ Presence } & \multicolumn{2}{|c|}{ Absence } & \multicolumn{2}{|c|}{ Total } \\
\hline & $\mathrm{N}$ & $\%$ & $\mathrm{~N}$ & $\%$ & $\mathrm{n}$ & $\%$ \\
\hline Absence & 151 & $\begin{array}{c}83 . \\
9 \\
16 .\end{array}$ & 507 & $\begin{array}{c}91 . \\
7\end{array}$ & 658 & $\begin{array}{c}89 . \\
8 \\
10 .\end{array}$ \\
\hline Presence & 29 & 1 & 46 & 8.3 & 75 & 2 \\
\hline Total & 180 & $\begin{array}{c}100 \\
.0\end{array}$ & 553 & $\begin{array}{c}100 \\
.0\end{array}$ & 733 & $\begin{array}{c}100 \\
.0\end{array}$ \\
\hline
\end{tabular}

Table 5. Relation between gap size in the observed quartiles $(\mu \mathrm{m})$ and the presence of external lesion.

\begin{tabular}{lcc}
\hline & \multicolumn{2}{c}{ Restoration adjacency } \\
\cline { 2 - 3 } \multicolumn{1}{c}{ Gap size $(\mu \mathrm{m})$} & $\begin{array}{c}\text { Sound } \\
\text { surface }\end{array}$ & $\begin{array}{c}\text { Surface with } \\
\text { lesion }\end{array}$ \\
\hline $1^{\text {st }}$ Quartile & 98.59 & 102.70 \\
$2^{\text {nd }}$ Quartile & 153.36 & 158.83 \\
(median) & 241.00 & 264.28 \\
\hline
\end{tabular}

(Non-parametric Mann-Whitney test: $p=0.765$ )

No statistical significance was noted in the occurrence of plane restorations or restorations with ledges at the points of analysis $(p=0.073)$ (Fig. 4). An association was noted between external lesions and the presence of ledges (Table 6).

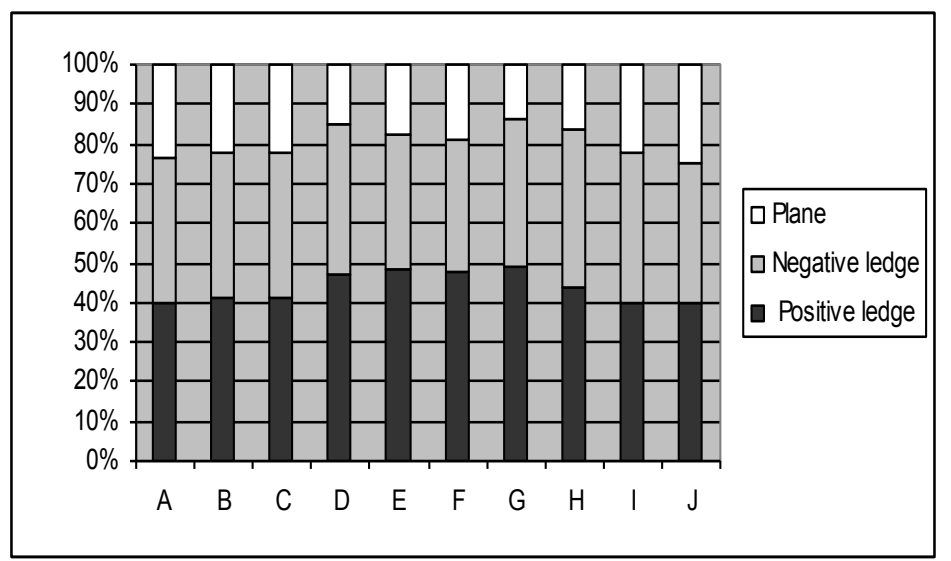

Figure 4. Classification of restorations at each analyzed

point. (Chi-squared test, $p=0.073$ )

Table 6. Relation between external lesion and classification of restorations at each analyzed point.

\begin{tabular}{|c|c|c|c|c|c|c|}
\hline \multirow{3}{*}{$\begin{array}{l}\text { External } \\
\text { lesion }\end{array}$} & \multicolumn{4}{|c|}{ Classification of restorations } & \multirow{2}{*}{\multicolumn{2}{|c|}{ Total }} \\
\hline & Planes & & & & & \\
\hline & $\mathrm{n}$ & $\%$ & $\mathrm{~N}$ & $\%$ & $\mathrm{n}$ & $\%$ \\
\hline Absence & 141 & $\begin{array}{c}89 . \\
2 \\
10\end{array}$ & $\begin{array}{c}51 \\
7 \\
12\end{array}$ & $\begin{array}{c}80 . \\
8 \\
19\end{array}$ & 658 & $\begin{array}{r}82 \\
5 \\
17\end{array}$ \\
\hline Presence & 17 & 8 & 3 & 2 & 140 & 5 \\
\hline
\end{tabular}

As to internal lesions, it was noted that $70.1 \%$ were active, $61.5 \%$ involved the internal enamel adjacent to the restoration, while $70.7 \%$ of these extended into the dentine. When external sites displaying no evidence of activity (healthy sites with inactive lesions) presented an internal lesion, $71.2 \%$ were active. There was an association between the presence of an external lesion and an internal lesion $(p<0.001)$ (Table 7).

Table 7. Relation between external lesion and internal lesion at each analyzed point.

\begin{tabular}{cccccccc}
\hline & \multicolumn{3}{c}{ External lesion } & & \\
\cline { 2 - 6 } Internal & \multicolumn{2}{c}{ Absence } & \multicolumn{3}{c}{ Presence } & \multicolumn{2}{c}{ Total } \\
\cline { 2 - 6 } lesion & $\mathrm{n}$ & $\%$ & $\mathrm{~N}$ & $\%$ & $\mathrm{n}$ & $\%$ \\
\hline \multirow{2}{*}{ Absence } & 517 & 78. & & 33. & & 70. \\
& & 6 & 47 & 6 & 564 & 7 \\
Presence & 141 & 21. & & 66. & & 29. \\
\hline \multirow{2}{*}{ Total } & & 4 & 93 & 4 & 234 & 3 \\
\hline
\end{tabular}

(Chi-squared test $=110.63 ; p<0.001)$ 
When the influence of the gap on the external caries/internal caries relation was brought into the analysis, it was confirmed that the relation held, independent of this variable $(p<0.05)$ (Table 8). However, there was an association between the absence of an external lesion and presence of an internal lesion in the presence of gap.

In order to ascertain the strength of this association, an analysis was designed where the outcome was presence of an internal lesion. The variables studied were external lesions, gap, and ledges. It was ascertained that the chance of a caries lesion being present in the cavity wall when a lesion is found externally is 5.5 times greater than at sites where no external evidence is seen. In the presence of gap, the chance of finding an internal lesion is 2.86 times greater than in the absence of gap and, in the presence of ledges, the chance is 3 times greater than when the restoration is plane (Table 9).

At the 141 sites where there was a lesion on the cavity wall without the presence of an external lesion (Table 7), the internal enamel of the cavity wall was affected at 77 sites. As a result, an internal lesion, only in the dentine, accounted for $8.0 \%$ of the total sample.

\section{Discussion}

The study of caries lesions adjacent to composite resin restorations in proximal boxes was conducted at a number of points of analysis. This methodology was justified due to the localized nature of the disease (KIDD; FEJERSKOV, 2004); this was proven by the diversity of situations found on one same proximal box.

One limitation of our study was the difficulty to obtain extracted teeth with resin restoration with initial secondary caries. This study found a low occurrence of secondary caries lesions, despite the precarious state of the adjacent composite resin restorations, shown by the presence of gap and ledges. Rezwani-Kaminski, Kaman and Gaengler (2002) and Gaengler et al. (2004) monitored compr ${ }^{\prime} \cdot$ resin restorations for 10 to 20 years and observed progres 27 deterioration of the restorations without any increase in the occurrence of adjacent caries which correlates with our results.

Table 8. Relation between external lesion and internal lesion in relation to gap presence at each analyzed point.

\begin{tabular}{|c|c|c|c|c|c|c|c|c|c|c|}
\hline \multirow[b]{3}{*}{ Internal lesion } & \multicolumn{8}{|c|}{ External lesion } & & \\
\hline & \multicolumn{2}{|c|}{ Absence with Gap } & \multicolumn{2}{|c|}{ Absence without Gap } & \multicolumn{2}{|c|}{ Presence with Gap } & \multicolumn{2}{|c|}{ Presence without Gap } & \multicolumn{2}{|c|}{ Total } \\
\hline & $\mathrm{n}$ & $\%$ & $\mathrm{n}$ & $\%$ & $\mathrm{n}$ & $\%$ & $\mathrm{n}$ & $\%$ & $\mathrm{n}$ & $\%$ \\
\hline Absence & 89 & 58.9 & 428 & $84.6^{*}$ & 2 & 6.9 & 25 & 54.3 & 544 & 74.2 \\
\hline Presence & 62 & $41.1^{*}$ & 79 & 15.4 & 27 & $93.1^{*}$ & 21 & $45.7^{*}$ & 189 & 25.8 \\
\hline Total & 151 & 100.0 & 506 & 100.0 & 29 & 100.0 & 46 & 100.0 & 733 & $\begin{array}{c}100 . \\
0\end{array}$ \\
\hline
\end{tabular}

Table 9. Relation between the variables (1) external lesion, (2) gap, and (3) classification of restorations with the outcome of presence of an internal lesion.

\begin{tabular}{|c|c|c|c|c|c|c|c|}
\hline \multirow{2}{*}{ Variables } & \multirow[b]{2}{*}{$\mathrm{n}$} & \multicolumn{2}{|c|}{ Internal lesion } & \multicolumn{2}{|c|}{ Odds Ratio } & \multicolumn{2}{|c|}{$\begin{array}{l}\text { Odds Ratio } \\
\text { adjusted }\end{array}$} \\
\hline & & $\mathrm{n}$ & $\%$ & Odds & (IC 95\%) & Odds & (IC 95\%) \\
\hline \multicolumn{8}{|l|}{ External lesion } \\
\hline Absence & 658 & 141 & (21.4) & 1.00 & & 1.00 & \\
\hline $\begin{array}{l}\text { Presence } \\
\text { Gap }\end{array}$ & 140 & 93 & $(66.4)$ & 7.26 & $(4.9-10.8)$ & 6.50 & $(3.8-11.2)$ \\
\hline Presence & 180 & 89 & $(49.4)$ & 4.43 & $(3.1-6.4)$ & 3.86 & $(2.6-5.7)$ \\
\hline Absence & 553 & 100 & (18.1) & 1.00 & & 1.00 & \\
\hline Classification & & & & & & & \\
\hline Plane & 158 & 14 & (8.9) & 1.00 & & 1.00 & \\
\hline Positive ledge & 349 & 116 & (33.2) & 5.12 & $(2.8-9.3)$ & 4.41 & $(2.3-8.6)$ \\
\hline Negative ledge & 291 & 291 & (35.7) & 5.72 & $(3.1-10.4)$ & 4.18 & $(2.1-8.3)$ \\
\hline
\end{tabular}

Rev. Fac. Odontol. Porto Alegre, v. 51, n. 3, p. 23-29, set./dez., 2010. 
Most of the external sites presented no lesions or inactive lesions. When these sites presented internal lesions, $71.2 \%$ of these were softened wall lesions. The process by which the lesions grow inactive starts from the surface and moves towards the inside of the lesion (THYLSTRUP; BRUUN; HOLMEN, 1994). The activity of internal lesions may represent a clinical stage of a process of arrestment. It should be noted that inactive dentine lesions are not as hard as sound dentine tissue (MARCHI, 2005). The presence of softened tissue in the cavity wall can also mean presence of residual demineralized dentine (KIDD, 2004).

The presence of a secondary caries lesion was associated with the cervical margin of the proximal boxes. One possible explanation for this finding may be the tendency for biofilm accumulation in this region (ÖZER, 1997). Other authors consider this region critical to secondary caries adjacent to composite resin restorations (BEZNOS, 2001; DEMARCO et al., 2001). These restorations may be problematic when it comes to sealing. The material may have to adhere to a very thin enamel and it may be broken when the composite resin contracts during polymerization (KIDD; TOFFENETTI; MJÖR, 1992). In the present study, gaps were observed more frequently in the cervical region, probably due to this phenomenon. Nevertheless, no difference in gap sizes was observed at the sites under study. ÖZER (1997) found a great prevalence of lesions in the cervical region associated with greater microbial accumulation, independent of gap size (CENCl et al., 2009). What seems important is the accumulation of bacterial biofilm, which may be linked to defects in the restoration. There was a high prevalence of other defects besides the gap, such as the presence of ledges (excess or absence of restorative material). In the present study, an association was found between ledges and secondary caries lesions. Although we observed a relation between restoration defects and the presence of lesions, it must be highlighted that the great majority of surfaces with defects did not present lesions. Numerous studies agree with these findings (KIDD; O'HARA, 1990; RUDOLPHY; VAN AMERONGEN; PENNING, 1995; PIMENTA; NAVARRO; CONSOLARO, 1995).

Over the years, some external indicators associated with the situation of the adjacent restoration have been used in the effort to diagnose wall lesions, with both amalgam and composite resin restorations. These indicators - such as discoloration, marginal deterioration, or gap - are the reason behind the excessive number of restoration replacements. Numerous studies have shown a nonrelation between these indicators and the presence of secondary caries lesion in the cavity wall (GOLDBERG et al., 1981; KIDD; O'HARA, 1990; KIDD; JOYSTON-BECHAL; BEIGHTON, 1994; KIDD; JOYSTON-BECHAL; BEIGHTON, 1995; RUDOLPHY; VAN AMERONGEN; PENNING 1995; PIMENTA; NAVARRO; CONSOLARO, 1995; KIDD; BEIGHTON, 1996; RUDOLPHY; VAN LOVEREN; VAN AMERONGEN, 1996; KIDD, 2001; FONTANA, GONZÁLES-CABEZAS, 2000). What makes it hard to diagnose an internal lesion is the lack of any identified relation with external evidence from the restorative treatment. This study found an association between the presence of external and internal lesions. This shows that the external evidence of the presence of a wall lesion may be identification of an external lesion adjacent to a restoration. It becomes clear that a careful examination of the tooth/restoration interface for any external lesion is necessary in order to prevent the occurrence of a wall lesion in the cavity (HANNIG et al, 2009). In addition to verifying the presence of any lesion, the examiner must also identify lesion activity. Any need for intervention should be based on this diagnosis. An important finding is the prevalence of inactive lesions adjacent to restorations, even in the presence of cavities, which confirms the possibility that the caries disease process may be arrested even when this far advanced (MALTZ et al., 2003).
At 62 sites, an association was found between present internal lesions and absent external lesions, in the presence of gap. Nevertheless, in measuring the degree of importance of each variable associated to the outcome of the internal lesion, it was proven that the chance of finding an internal lesion is doubled when in the presence of an external lesion, as compared to the other variables under study, i.e., gap and ledges. This further underscores the value of a thorough clinical exam adjacent to the restoration. Likewise of import is the analysis of the involvement of enamel on an internal lesion, as observed in situations where it was not possible to detect an external lesion. The involvement of enamel on an internal lesion can indicate the lesion's external opening (THOMAS et al, 2007). The region where the enamel is affected is not visible upon external examination, most likely because of wear on the porous surface of the external face and consequent continuation of an internal enamel lesion (KIDD; FEJERSKOV, 2004). Considering this, the phenomenon of a "wall lesion" without any external involvement drops to roughly $8 \%$ of all examined sites. A wall lesion without any external evidence may represent either remaining demineralized tissue, rather than the progression of lesion (KIDD, 2004), or a caries lesion in the inside wall, caused by microleakage of bacteria and its products at the toothrestoration interface (HALS; SIMONSEN, 1971).

This study shows that the great majority of secondary caries lesions begin on the external surface adjacent to the restoration. This location can be controlled and deactivated, as proven by the greater prevalence of inactive lesions, at the cavity level as well. Despite the relation between factors that prompt the accumulation of bacterial biofilm-gap and ledges-and the occurrence of lesions, many sites were found to present defects and an adjacent sound surface. The mere presence of a defective restoration should not be the reason for an operative intervention. The observation of the presence of a lesion and its activity should guide the need for treatment, taking into account the activity of the patient's caries disease. A secondary caries lesion is not an isolated event, but rather a primary external lesion that occurs around restorations and its treatment should be aimed at the patient's needs in relation to the disease.

\section{References}

ANDERSON, M.H. Current concepts of dental caries and its prevention. Oper. Dent., Seattle, Suppl. no. 6, p. 11-18, 2001.

BEZNOS, C. Microleakage at the cervical margin of composite class II cavities with different restorative techniques. Oper. Dent., Seattle, v. 26, no. 1, p. 60-69, Jan./Feb. 2001.

CENCI, M.S. et al. Relationship between gap size and dentine secondary caries formation assessed in a microcosm biofilm model. Caries Res., Basel, v. 43, no. 2, p. 97- 102, 2009.

DEMARCO, F.F. Influence of different restorative techniques on micro leakage in Class II cavities with gingival wall in cement. Oper. Dent., Seattle, v. 26, no. 3, p. 253-259, May/June 2001.

FLEISS, J.C. Statistical methods for rate proportions. 2. ed. New York: John Wiley and Sons, 1981.

FONTANA, M.; GONZALEZ-CABEZAS, C. Secondary caries and restoration replacement: An unresolved problem. Compend. Contin. Educ. Dent., Jamesburg, N.J., v. 21, no. 1, p.15-27, Jan. 2000.

GAENGLER, P. et al. Micromorphological evaluation of posterior composite restorations - a 10-year report. J. Oral Rehabil., Oxford, v. 31, no. 10 , p. 991-1000, Oct. 2004. 
GOLDBERG, J. et al. Cross-sectional clinical evaluation of recurrent enamel caries, restoration marginal integrity, and oral hygiene status. J. Am. Dent. Assoc., Chicago, v. 102, no. 5, p. 635-641, May 1981.

HALS, E.; SIMONSEN, T.L. Histopathology of in vitro caries around silver amalgam fillings. Caries Res., Basel, v. 6, no. 1, p. 16-33, 1971.

HANNIG, C. et al. Validity of decision criteria for replacement of fillings. Schweiz. Monatsschr. Zahnmed., Bern, v. 119, no. 4, p. 328338, 2009.

HILTON, T. J. Can modern restorative procedures and materials reliably seal cavities? In vitro investigation. Part 1. Am. J. Dent., San Antonio, v. 15, no. 3, p. 198-210, June 2002.

HILTON, T. J. Can modern restorative procedures and materials reliably seal cavities? In vitro investigation. Part 2. Am. J. Dent., San Antonio, v. 15, no. 4, p. 279-289, Aug. 2002.

ITOTA, T. et al. Effect of adhesives on the inhibition of secondary caries around compomer restorations. Oper. Dent., Seattle, v. 26, no. 5, p. 445-450, Sept./Oct. 2001.

KIDD, E.A.; O'HARA, J.W. The caries status of occlusal amalgam restorations with marginal defects. J. Dent. Res., Chicago, v. 69, no. 6, p. 1275-1277, June 1990.

KIDD, E. A.; TOFFENETTI, F.; MJÖR, I. A. Secondary caries. Int. Dent. J., London, v. 42, no. 3, p. 127-138, June 1992.

KIDD, E. A.; JOYSTON-BECHAL, S.; BEIGHTON, D. Diagnosis of secondary caries: a laboratory study. Br. Dent. J., London, v.176, no. 4, p. 135-139, Feb. 1994.

KIDD, E.A.; JOYSTON-BECHAL, S.; BEIGHTON, D. Marginal ditching and staining as a predictor of secondary caries around amalgam restorations: a clinical and microbiological study. J. Dent. Res., Chicago, v. 74, no. 5, p. 1206-1211, May 1995.

KIDD, E.A.; BEIGHTON, D. Prediction of secondary caries around tooth-colored restorations: a clinical and microbiological study. J. Dent. Res., Chicago, v. 75, no. 12, p. 1942-1946, Dec. 1996.

KIDD, E. A. Diagnosis of secondary caries. J. Dent. Educ., Washington, v. 65, no. 10, p. 997-1000, Oct. 2001.

KIDD, E. A.; FEJERSKOV, O. What constitutes dental caries? Histopathology of carious enamel and dentin related to the action of cariogenic biofilms. J. Dent. Res., Chicago, v. 83, Spec. no. C, p. 35$38,2004$.

KIDD, E. A. How 'clean' must a cavity be before restoration? Caries Res., Basel, v. 38, no. 3, p. 305-313, May/June 2004.

LAI, G.; LI, M. Secondary caries. In: LI, M.-Y. Contemporary approach to dental caries. Rijeka, Croatia: InTech, 2012. Chap. 22, p. 423-442.

MAGALHÃES, C.S. Validity of staining and marginal ditching as criteria for diagnosis of secondary caries around occlusal amalgam restorations: an in vitro study. Braz. Dent J., Ribeirão Preto, v. 20, no. 4, p. 307-313, 2009.

MALTZ, M. et al. Results after two years of non-operative treatment of occlusal surface in children with high caries prevalence. Braz. Dent. J., Ribeirão Preto, v. 14, no. 1, p. 48-54, 2003.

MANHART J. et al. Marginal quality of tooth-colored restorations in class II cavities after artificial aging. Oper. Dent., Seattle, v. 26, no. 4, p. 357-366, July/Aug. 2001.

MARCHI, J. Análise da dentina de dentes decíduos submetidos ao capeament pulpar indireto com remoção parcial de tecido cariado.
2005. 51 f. Dissertação (Mestrado)- Faculdade de Odontologia, Universidade Federal do Rio Grande do Sul, Porto Alegre, 2005.

$\mathrm{MO}, \mathrm{S}$.S. et al. The microfloral analysis of secondary caries biofilm around class I and class II composite and amalgam fillings. BMC Infect. Dis., London, v. 17, no. 10, p. 241, Aug. 2010.

NEME, A.L.; EVANS, D.B.; MAXSON, B.B. Evaluation of dental adhesive systems with amalgam and resin composite restorations: comparison of micro leakage and bond Strength Results. Oper. Dent., Seattle, v. 25, no. 6, p. 512-519, Nov./Dec. 2000.

OKUDA, M. Relationship between nanoleakage and long-term durability of dentin bonds. Oper. Dent., Seattle, v. 26, no. 6, p. 482490, Sept./Oct. 2001.

ÖZER, L. The relation between gap size, microbial accumulation and the structural features of natural caries in extracted teeth with class II amalgam restorations. A stereo and polarized light microscopic study. 1997. 98 f. PhD thesis. School of Dentistry - Faculty of Health Sciences - University of Copenhagen, Denmark, 1997.

PIMENTA, L.A., NAVARRO, M.F.L.; CONSOLARO, A. Secondary caries around amalgam restorations. J. Prosthet. Dent., St. Louis, v. 74, no. 3, p. 219-222, Sept. 1995.

REZWANI-KAMINSKI, T.; KAMAN, W.; GAENGLER, P. Secondary caries susceptibility of teeth with long term performing composite restorations. J. Oral Rehabil., Oxford, v. 29, no. 12, p. 1131-1138, Dec. 2002.

RUDOLPHY, M.P.; VAN AMERONGEN, J.P.; PENNING, C. Grey discoloration and marginal fracture for the diagnosis of secondary caries in molars with occlusal amalgam restorations: an in vitro study. Caries Res., Basel, v. 29, no. 5, p. 371-376, 1995.

RUDOLPHY, M. P., VAN LOVEREN, C.; VAN AMERONGEN, J.P. Grey discoloration and marginal fracture for the diagnosis of secondary caries in teeth with class II amalgam restorations: an in vitro study. Caries Res., Basel, v. 30, no. 3, p. 189-193, 1996.

THOMAS, R.Z. Approximal secondary caries lesion progression, a 20week in situ study. Caries Res., Basel, v. 41, no. 5, p. 399-405, 2007. THYLSTRUP, A.; BRUUN, C.; HOLMEN, L. In vivo caries models-mechanisms for caries initiation and arrestment. Adv. Dent. Res., Washington, v. 8, no. 2, p. 144-157, July 1994.

WHITE, D.J. Reactivity of fluoride dentifrices with artificial caries I. Effect on early lesions, $F$ uptake, surface hardening and remineralization. Caries Res., Basel, v. 21, no. 2, p. 126-140, 1987. 